\title{
Giant cell tumour of bone: new treatments in development
}

\author{
A. López-Pousa $\cdot$ J. Martín Broto $\cdot$ \\ T. Garrido $\cdot$ J. Vázquez
}

Received: 5 December 2014/ Accepted: 18 December 2014/Published online: 24 January 2015

(C) The Author(s) 2015. This article is published with open access at Springerlink.com

\begin{abstract}
Giant cell tumour of bone (GCTB) is a benign osteolytic tumour with three main cellular components: multinucleated osteoclast-like giant cells, mononuclear spindle-like stromal cells (the main neoplastic components) and mononuclear cells of the monocyte/macrophage lineage. The giant cells overexpress a key mediator in osteoclastogenesis: the RANK receptor, which is stimulated in turn by the cytokine RANKL, which is secreted by the stromal cells. The RANK/RANKL interaction is predominantly responsible for the extensive bone resorption by the tumour. Historically, standard treatment was substantial surgical resection, with or without adjuvant therapy, with recurrence rates of 20-56\%. Studies with denosumab, a monoclonal antibody that specifically binds to RANKL, resulted in dramatic treatment responses, which led to its approval by the United States Food and Drugs Administration (US FDA). Recent advances in the understanding of GCTB pathogenesis are essential to develop new treatments for this locally destructive primary bone tumour.
\end{abstract}

Keywords Giant cell tumour of bone - Pathophysiology · Surgery $\cdot$ Denosumab

A. López-Pousa

Hospital de la Santa Creu i Sant Pau, Barcelona, Spain

A. López-Pousa ( $₫)$

Medical Oncology Department, Hospital de la Santa Creu i Sant Pau, Autonomous University of Barcelona, Mas Casanovas 90, ES-08041 Barcelona, Spain

e-mail: alopezp@santpau.cat

J. M. Broto

Hospital Universitari Son Espases, Palma de Mallorca, Spain

T. Garrido · J. Vázquez

Amgen S.A., Barcelona, Spain

\section{Introduction: new insights into pathophysiology}

Definition, epidemiology and natural course

Giant cell tumour of bone (GCTB) is a rare osteolytic tumour that is responsible for approximately $6 \%$ of all primary bone tumours. Reported annual incidence ranges between 1 and 6 per 10 million persons [1,2] to approximately 1 per million in the US, Western Australia, Japan and Sweden [3]. It typically affects adults aged between 20 and 50 years [4-6], with a slightly higher incidence among females $(1.7$ per 10 million in females versus 1.5 per 10 million in males) [1, 4-6]. GCTB is typically located in the epiphysis of bones, causing localised tenderness and swelling, reduced joint mobility, and pain that is often severe and intractable [6]. It usually develops in long bones but can also occur in unusual locations. The Enneking staging classification, based on radiological, histological and clinical features, is the most commonly used (Table 1) [7]. There is also a radiological grading system established by Campanacci et al. [8] that classifies GCTB into three radiographic types (I, intramedullary lesion confined to bone; II, thinned, expanded cortex, III, cortical breakout), and is roughly comparable with the staging system of Enneking et al. [7]

Symptoms are variable; some patients may be asymptomatic until they develop a pathologic fracture while others complain of pain at the adjacent joint and limited range of motion. There may also be swelling and even a visible mass, if the tumour has grown for a long time. Other commonly reported symptoms include muscular or nerve pain [6].

The tumour is locally aggressive and destructive, and it grows rapidly, destroying bone and spreading into surrounding soft tissues [9]. If it is surgically resected, there is 
Table 1 Enneking classification of GCTB [7]

\begin{tabular}{lll}
\hline Stage & $\%$ & Description \\
\hline Stage I (latent) & 15 & Confined totally by bone \\
& Asymptomatic \\
& Inactive on bone scan \\
& Histologically benign \\
Stage II (active) & Expanded cortex with no breakthrough \\
& & Symptomatic \\
& Often have pathological fracture \\
& Active on bone scan \\
Stage III (aggressive) & Histologically benign \\
& Rapidly growing mass \\
& Cortical perforation with soft tissue mass \\
& May metastasize \\
& & Symptomatic \\
& Extensive activity on bone scan \\
& Histologically benign \\
Malignant & Sarcomatous lesion contiguous with benign GCT
\end{tabular}

a substantial probability of recurrence, which seems to be greater in some locations associated with more difficult treatment, such as the distal radius and the proximal femur [10]. In the absence of treatment, the continued and unchecked tumour growth leads to complete destruction of the bone, physical deformity and the possibility of loss of limb.

The most common site of metastasis is the lung, occurring at a frequency of 1-6\% [11, 12]. Pulmonary metastases are usually histologically benign and their course is indolent. The standard of care is surgical resection, and prognosis is generally good. If resection is not possible, they can be left untreated $[6,11,13]$.

Rarely, in less than $1 \%$ of cases, GCTB may undergo malignant transformation that is known to result in a poor prognosis for the patient $[6,14]$. The malignancy may arise as a result of dedifferentiation of the primary tumour or secondary to radiation therapy (approximately $50 \%$ of cases) [11]. The most commonly observed transformation is to a high-grade sarcoma, usually an osteosarcoma, however, in rare cases this transformation may result in the formation of a fibrosarcoma or a classically denominated malignant fibrous histiocytoma. The mean time after initial GCTB diagnosis to malignant transformation is around 19 years in patients with spontaneous transformation and around 9 years in post-radiation cases [11].

\section{Pathophysiology}

The histopathology of GCTB reveals the presence of marked haemorrhage and three major cell types: multinucleated giant cells, stromal cells and mononuclear cells of the monocyte/macrophage lineage $[15,16]$.
The spindle-like stromal cells are the main neoplastic components, and appear to be activated by fibroblasts that secrete type I and III collagen and possess parathormone receptors [17, 18]. They promote giant cell formation by expressing and secreting a variety of chemotactic factors (cytokines such as interleukin [IL]-6, IL-8, IL-11, IL-17, IL34 , basic fibroblast growth factor [b-FGF], tumour necrosis factor [TNF]- $\alpha$, vascular endothelial growth factor [VEGF], macrophage colony-stimulating factor [M-CSF], RANKL, cathepsin $\mathrm{K}$; chemokines such as IL-8, TGF- $\beta 1$ and stromal derived factor-1 [SDF-1]; and enzymes such as matrix metalloproteinase [MMP]-9 and MMP-13) [19-22]. All these factors serve to engage and differentiate circulating monocytes into macrophages [23]. Of these factors, SDF-1 appears to act as a chemoattractant involved in the recruitment of monocytes [23]. Furthermore, some studies have correlated the expression of VEGF and MMP-9 with the extent of bone destruction and probability of recurrence [24].

Giant cells are directly responsible for the increased bone resorption observed within the lesion [25, 26]. They are considered to be reactive macrophages that have acquired osteoclastic activity as a result of their stimulation by stromal cells, which modifies their gene expression pattern within the osseous environment [27]. Giant cells also drive increased expression of a key mediator in osteoclastogenesis: the RANK receptor [28]. Activation of this receptor by RANKL, which is secreted by stromal cells, promotes osteoclast formation, activation, function, and survival [29-32]. Thus, leading to the increased level of bone resorption observed within the GCTB lesion. In addition, the activated osteoclasts, in turn, release tumour growth factors into the bone microenvironment, initiating a tumour/bone vicious cycle (Fig. 1a) [33-35]. 
The underlying cause of the increased RANKL expression by stromal cells is unknown, however, this phenomenon is reduced after elimination of the giant cells [32]. Conversely, giant cells are clearly dependent on RANKL signalling by stromal cells $[32,36]$. Thus, it is possible that GCTB promotes a pathological variation of the normal physiological interdependence of osteoblast and osteoclast populations in bone [37, 38].

Cytogenetic abnormalities have been observed in up to $72 \%$ of patients with GCTB, yet to date, no uniform aberrations have been identified [15, 39, 40]. Telomeric associations (reductions in telomere length with an average loss of 500 base pairs) are the most frequent chromosomal aberrations and the telomeres most commonly affected are 11 p, 13p, 14p, 15p, 19q, 20q and 21p [39, 40].

There is also a hypothesis that the origin of GCTB could be linked to a form of bone injury, as in some cases GCTB appears in locations associated with prior trauma [41, 42]. In this scenario, GCTB could be considered a local reactive condition secondary to a haemorrhage due to bone injury and/or defective collagen in the matrix or in the vessel wall. It is possible that the haemorrhage serves to provide fresh monocytes and plasma proteins that initiate activation of stromal cells, which in turn stimulate conversion of giant cells into active osteoclasts [41]. Once the primary lesion occurs, the stromal cells would be capable of re-forming the tumour in secondary tumour sites or after surgical removal, thanks to their proliferative and tumour-initiating properties [17, 43, 44]. However, it seems that other transformational factors are required since injection of isolated stromal cells into immunocompromised mice does not produce giant cells $[45,46]$. Some studies suggest that metastases could result from tumour emboli travelling to distant sites [47, 48].

\section{Treatment}

\section{Surgical treatment}

Surgical removal of the tumour with wide excision or intralesional curettage and placement of cement (polymethyl methacrylate) has been historically the preferred treatment for GCTB [10, 49-52]. The challenge with surgery is to remove as much of the tumour as possible while leaving the joint intact. Wide excision is associated with poor functional outcome and greater surgical complications [53-55]. Therefore, intralesional curettage has been the mainstay of treatment for the majority of patients with stage I or II tumours. Wide excision is usually reserved for more aggressive stage III tumours with extraosseous extension or otherwise unresectable tumours [6, 56, 57]. However, sometimes the tumour is unresectable or surgery is not recommended due to age, patient comorbidities or risk of severe morbidity, such as joint removal or loss of limbs.

Aggressive GCTBs may require wide excision and reconstruction with a modular endoprosthesis; the most commonly used synthetic grafts are made from polymethyl methacrylate (PMMA). These grafts are known to generate an exothermic reaction that increases thermal necrosis of tumour cells and an inflammatory reaction, consequently resulting in an improved patient recovery and tumour removal [58, 59].

The main complications associated with surgery include pathologic fracture and postoperative infection. Postoperative infection occurs in $2-25 \%$ of patients, and its incidence is probably greater with more extensive surgery involving en bloc resection and placement of an endoprosthesis [60-63]; whereas pathologic fracture is associated with an increased rate of recurrence and a poorer functional outcome [64].

There is a recognised tendency for GCTBs to recur locally in many cases following surgery, even in the soft tissues adjacent to the primary bone location $[5,10,65$, 66]. In one of the largest published cohorts, a multicentre retrospective study in 294 Scandinavian patients, Kivioja et al. [52] reported recurrence rates ranging between $20 \%$ for patients with PMMA cementation following intralesional curettage, and $56 \%$ for patients without cementation. In contrast, wide excision is reported to be associated with a lower risk of local recurrence (0-12\%) than intralesional curettage (12-65\%) [5, 67-69]. The use of improved surgical techniques, such as extensive mechanical burr drilling of the tumour wall after curettage or adjuvant cryoablation with liquid nitrogen, has further decreased recurrence rates in some centres, but these techniques have not yet been widely adopted. In the study by Malawer et al. [70] only $2.3 \%$ of patients recurred after primary treatment with cryosurgery, although this percentage increased to $7.9 \%$ when second-line treatments were also considered.

\section{Chemical adjuvant therapy}

Currently, there is no standard or approved first-line medical treatment for GCTB. Surgical treatment may be combined with chemical adjuvant therapies. Some of the treatments commonly applied to the affected area are: alcohols [59, 71, 72], phenol [71, 73], hydrogen peroxide [71, 74, 75], and zinc chloride [76]. Hydrogen peroxide has been found to increase the penetration of phenol into the surrounding tissues [75]. Use of chemical adjuvants has been shown to reduce the percentage of recurrences in some studies [77], although others failed to demonstrate any impact [78]. Furthermore, these adjuvants must be used with caution, to avoid chemical burns. 
Fig. 1 a Mechanism of increased bone resorption in GCTB: central role of the RANK/RANKL interaction [33-35]. b Proposed mechanism of action of denosumab in GCTB [96]

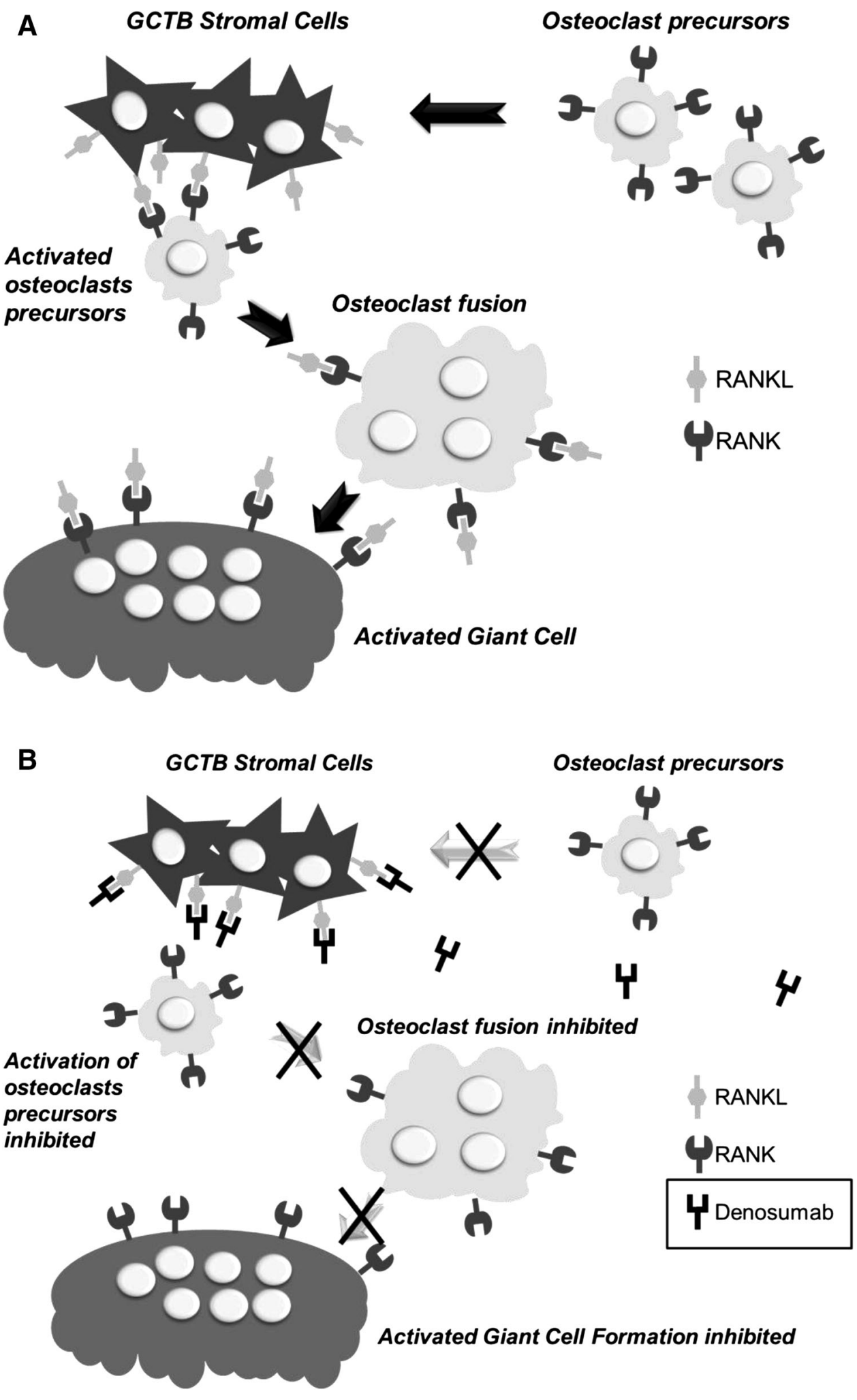

\section{Radiation therapy}

Radiation therapy has been used to treat GCTB since 1932 [79] and its efficacy has been demonstrated by several studies in patients for whom surgery was not feasible [80, 81]. Specialised techniques such as 3-D conformal radiotherapy (RT) and intensity-modulated radiotherapy (IMRT) have been associated with good local control rates in 
patients with GCTB in locations that are not accessible by surgical resection [82, 83]. However, some reports have suggested an increased risk of malignant transformation into post-radial sarcoma [84].

The better safety profile of the new drugs available to inhibit osteoclastogenesis has decreased the use of RT in GCTB [85].

\section{Embolisation and laser photoablation}

Embolisation is made by hyperselective catheterisation and embolisation of the arteries that feed the pathological lesion with the most appropriate embolic agent. Typically, Gelfoam, polyvinyl alcohol (PVA) particles, and coils are used for embolisation; other agents include tissue adhesive, ethanol, and microfibrillar collagen. Occlusion of the vessels decreases the volume of the tumour, but multiple procedures are frequently necessary [86]. Photoablation with an argon laser is another therapy that can lead to successful tumour necrosis [87].

Given the high vascularity and morbidity associated with surgical resection and/or radiation therapy, embolisation has been reported to be useful within 24-48 h prior to these therapies $[88,89]$, to prevent recanalisation. The combined use of preoperative embolisation and adjuvants, including radiation therapy and intraoperative phenol and nitrogen, can decrease local recurrence to less than $10 \%$ [90].

Serial embolisation is also used as primary treatment in some patients with GCTB of the extremities, especially for tumours with large cortical defects or joint involvement and for those with large GCTBs of the sacrum. This procedure has a low morbidity rate and has been shown to be effective in preserving function and relieving pain in selected patients [91-93].

\section{Drug therapy}

\section{Denosumab}

In parallel with an improved understanding of the pathogenesis of the tumour, other treatment options for GCTB are continuously being explored. The discovery of the involvement of the RANK/RANKL pathway has recently led to the use of the monoclonal antibody denosumab [94]. To date, denosumab is the first and only drug approved by the United States (US) Food and Drug Administration (FDA) and, in Europe, by the European Medicine Agency (EMA) for GCTB [95].

Indication Since June 2013, denosumab is indicated in the US for treatment of adults and skeletally mature adolescents with GCTB that is unresectable or where surgical resection is likely to result in severe morbidity [95]. In
Europe, the European Medicines Agency also approved it for GCTB in September 2014. In addition, denosumab is indicated for the prevention of skeletal-related events in patients with bone metastases from solid tumours in the US and in the European Union [94, 95].

The recommended dose of denosumab in the GCTB indication is $120 \mathrm{mg}$ administered once every 4 weeks with additional $120 \mathrm{mg}$ doses on days 8 and 15 of the first month of therapy. Denosumab is administered as a single subcutaneous injection in the upper arm, upper thigh, or abdomen [94, 95].

Mechanism of action Denosumab is a human monoclonal antibody [immunoglobulin G2 (IgG2)] that targets and binds RANKL with high affinity and specificity, preventing activation of its receptor, RANK, on the surface of giant cells, osteoclast precursors and osteoclasts. Prevention of the RANK/RANKL interaction inhibits osteoclast formation, function, and survival, thereby decreasing bone resorption in GCTB (Fig. 1b) [96].

Pharmacokinetic and pharmacodynamic properties Following subcutaneous administration, rapid and prolonged absorption of denosumab has been shown [96, 97]. It has been detected in the serum within $1 \mathrm{~h}$ of dosing and for up to 9 months following a single dose (maximal serum concentrations achieved between 5 and 21 days) [96, 97]. With multiple dosing (120 mg subcutaneously, every 4 weeks), there was an approximately twofold increase in serum concentrations in treated patients with bone metastases secondary to solid tumours. Steady state is attained by 6 months and, at steady state, the mean serum trough concentration is $20.5 \mu \mathrm{g} / \mathrm{mL}$ (standard deviation $13.5 \mu \mathrm{g}$ / $\mathrm{mL}$ ) and mean elimination half-life is 28 days [94].

Clinical development in GCT The safety and efficacy of denosumab for the treatment of GCTB in adults or skeletally mature adolescents were demonstrated in two phase 2, open-label studies. All patients received $120 \mathrm{mg}$ of denosumab subcutaneously every 4 weeks with additional doses on days 8 and 15 of the first cycle of therapy [98, 99].

Efficacy A single-arm, open-label, pharmacodynamic and proof of concept study evaluated the safety and efficacy of denosumab in 37 patients $\geq 18$ years with recurrent or unresectable GCTB [99].

Eighty-six percent (95\% CI 70-95) of patients $(n=30)$ met the criteria for tumour response (elimination of $\geq 90 \%$ of giant cells or no radiological progression of the target lesion): 20 based on histology and 10 based on radiology. Histological results showed near-complete or complete elimination of giant cells in all patients for whom histology was available. Improvement in functional status or reduced pain were reported in $84 \%$ of patients (95\% CI 66-95; 
$n=26$ ), and $29 \%$ of patients (95\% CI $14-48 ; n=9$ ) had evidence of bone repair [99].

The second study was an open-label, single-arm, parallelcohort, proof of concept, and safety trial conducted in 282 adult patients with primary or recurrent GCTB distributed in 3 cohorts [98]: cohort 1, 170 patients who had surgically unsalvageable disease as determined by the treating surgeon (e.g. sacral, spinal, or multiple GCTB lesions including pulmonary metastases); cohort 2, 101 patients with a planned surgery that was associated with severe morbidity (e.g. joint resection, limb amputation, hemipelvectomy); and cohort 3,11 patients who transitioned from the previous denosumab GCTB study [99] and continued denosumab treatment on this study. The primary efficacy outcome measures were time to disease progression in cohort 1 and the proportion of patients without any surgery at 6 months in cohort 2 [98]. An interim analysis was published when more than 200 patients had had an opportunity to complete 6 months of treatment after enrolment [98].

At the time of the interim analysis, median time to disease progression in cohort 1 was not reached, and the best response rate (complete or partial) determined by investigator was $41 \%$ in cohort 1 and $58 \%$ in cohort 2 (Table 2). In a retrospective, independent imaging analysis that evaluated tumour response in patients from all three cohorts who received imaging as part of their standard of care $(N=190)$, the overall objective response rate (RECIST 1.1) was $25 \%$ (95\% CI 19, 32), with all responses documented as partial responses. The estimated median time to response was 3 months. In the 47 patients with an objective response, median duration of follow-up was 20 months (range 2-44 months), and $51 \%$ (24/47) had a duration of response lasting at least 8 months. Three patients experienced disease progression following response. Combining three different response criteria (RECIST, European Organization for Research and Treatment of Cancer (EORTC) and Modified Choi criteria), the best objective response rate was $72 \%$ (Table 2) [98].

Clinical benefit was observed in 40 and $61 \%$ of patients in cohorts 1 and 2 , respectively, with pain reduction the most commonly observed benefit (Table 2; Fig. 2). Of the 100 patients in cohort 2 for whom surgery was planned at baseline, 90 (90\%) patients had either no surgery $(n=74$; $74 \%)$ or underwent a less morbid procedure $(n=16$; $16 \%)$ compared with the surgical procedure planned at baseline [98] (Table 3; Fig. 2). Median follow-up for cohort 2 was 9.2 months (IQR 4.2-12.9). Of the 71 patients who were on study for at least 6 months, $64(90 \%)$ did not

Table 2 Main results of the phase 2 study of denosumab in GCTB [98]

\begin{tabular}{|c|c|c|c|c|c|}
\hline & \multicolumn{5}{|c|}{ Best response (investigator-determined) } \\
\hline & \multicolumn{3}{|c|}{ Cohort 1: surgically unsalvageable } & \multicolumn{2}{|c|}{ Cohort 2: salvageable, surgery planned } \\
\hline Complete response, $\%(n / N 1)$ & \multicolumn{3}{|l|}{$5(8 / 159)$} & \multicolumn{2}{|c|}{$18(17 / 93)$} \\
\hline Partial response, \% $(n / N 1)$ & \multicolumn{3}{|l|}{$36(57 / 159)$} & \multicolumn{2}{|c|}{$40(37 / 93)$} \\
\hline Stable disease, $\%(n / N 1)$ & \multicolumn{3}{|l|}{$58(93 / 159)$} & \multicolumn{2}{|c|}{$41(38 / 93)$} \\
\hline \multirow[t]{2}{*}{ Disease progression, $\%(n / N 1)$} & \multicolumn{3}{|l|}{$1(1 / 159)$} & \multicolumn{2}{|c|}{$1(1 / 93)$} \\
\hline & \multicolumn{5}{|c|}{ Best clinical benefit (investigator-determined) } \\
\hline Pain reduction, $\%(n / N)$ & \multicolumn{3}{|l|}{$28(48 / 169)$} & \multicolumn{2}{|c|}{$50(50 / 100)$} \\
\hline Improved mobility, $\%(n / N)$ & \multicolumn{3}{|l|}{$22(38 / 169)$} & \multicolumn{2}{|c|}{$33(33 / 100)$} \\
\hline Improved function, $\%(n / N)$ & \multicolumn{3}{|l|}{$19(32 / 169)$} & \multicolumn{2}{|c|}{$23(23 / 100)$} \\
\hline \multirow[t]{3}{*}{ Other, \% $(n / N)$} & \multicolumn{3}{|l|}{$4(6 / 169)$} & \multicolumn{2}{|c|}{$10(10 / 100)$} \\
\hline & & \multicolumn{4}{|c|}{ Best response (independent imaging assessment) } \\
\hline & & Overall & RECIST 1.1 & EORTC & Inverse Choi \\
\hline Objective response $(\mathrm{OR})^{\mathrm{a}}, \%(n / N 2)$ & & $72(136 / 190)$ & $25(47 / 187)$ & $96(25 / 26)$ & $76(134 / 176)$ \\
\hline Median time to OR, months & & 3.1 & not reached & 2.7 & 3 \\
\hline OR sustained $\geq 24$ weeks, $\%(n / N 2 *)$ & & $68(76 / 111)$ & $24(26 / 109)$ & $92(11 / 12)$ & $75(76 / 102)$ \\
\hline Tumour control $^{\mathrm{b}}$ sustained $\geq 24$ weeks, & $(n / N 2 *)$ & $98(109 / 111)$ & $99.1(108 / 109)$ & $100(12 / 12)$ & $99(101 / 102)$ \\
\hline
\end{tabular}

$N 1$ number of enrolled patients who received $\geq 1$ dose of denosumab and had a disease status evaluation

$N$ number of enrolled subjects who were eligible for the study and received $\geq 1$ dose of denosumab

$N 2$ Patients with $\geq 1$ evaluable timepoint assessment

RECIST response evaluation criteria in solid tumours, EORTC European organization for research and treatment of cancer

*Patients with timepoint assessments $\geq 24$ weeks apart

${ }^{\text {a }}$ Objective response $=$ complete + partial response

b Tumour control $=$ complete + partial response + stable disease 
Fig. 2 Clinical benefits (investigator-determined) observed with denosumab in patients with primary or recurrent GCTB participating in a phase 2, open-label study [98]

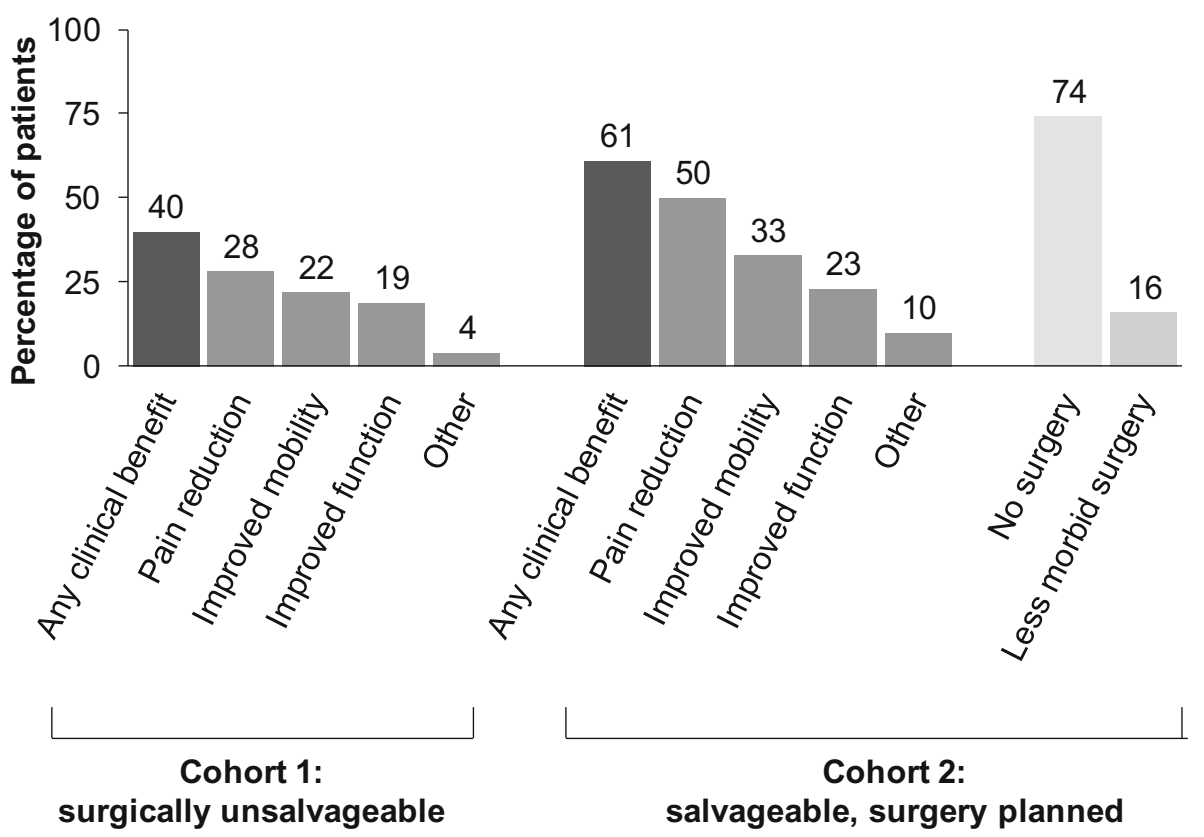

Table 3 Planned versus actual surgeries in cohort 2 of the phase 2 study of denosumab in GCTB [98]

\begin{tabular}{lll}
\hline & Planned & Actual total \\
\hline Surgical procedure, $n^{\text {a }}$ & $(N=100)$ & $(N=26)$ \\
Total number of surgeries & 100 & 26 \\
Major surgeries & 44 & 3 \\
Hemipelvectomy & 4 & 0 \\
Amputation & 17 & 0 \\
Joint or prosthesis replacement & 9 & 1 \\
Joint resection & 14 & 2 \\
En bloc resection & 37 & 6 \\
En bloc excision & 4 & 0 \\
Marginal excision & 1 & 0 \\
Curettage & 13 & 16 \\
Other & 1 & 1 \\
No surgery & $\mathrm{NA}$ & 74 \\
\hline
\end{tabular}

$N A$ not applicable

${ }^{a}$ Data are $n$ in the efficacy analysis set. Procedures are in decreasing order of morbidity

have surgery by month 6 . Of the 26 patients who had surgery, the median time to surgery was 23.8 months.

Safety In the first phase 2 study, $89 \%$ of patients experienced an adverse event (AE) with the most frequently reported AEs being pain in the extremity, back pain, and headache. One case of osteonecrosis of the jaw (ONJ) was also reported [100].

In the second phase 2 study, $84 \%$ of patients who received at least one dose of denosumab reported an AE. Commonly reported AEs included arthralgia, headache, nausea, and fatigue. The incidence of hypercalcemia was
$5 \%$, none of which were judged to be serious, and the incidence of ONJ was $1 \%$ (3 patients) [98].

During treatment with denosumab, it is recommended that calcium levels should be monitored, and all patients should receive daily calcium and vitamin D supplementation. A dental examination with appropriate preventive dentistry should be considered before initiating treatment with denosumab and invasive dental procedures should be avoided during the course of treatment. Oral examinations should be performed regularly by both the patient and physician [94, 95].

Other studies

A case series also suggested that preoperative treatment with denosumab induces dramatic sclerosis and reconstitution of cortical bone, achieving tumour necrosis in $90 \%$ of patients. The authors reported that, after denosumab treatment, subsequent surgical resection was easier in cases of aggressive tumours and that denosumab should also be considered as a stand-alone treatment in patients who are poor surgical candidates or in cases where the tumour is in a location difficult to treat surgically [101]. There are also some case reports of successful use of denosumab in children [102], although it has not been formally assessed in this population and is not recommended for use.

\section{IFN- $\alpha /$ PEG-IFN}

The increased expression of several angiogenic growth factors observed in GCTB led to the use of interferon alfa 
(IFN- $\alpha$ ) as an anti-angiogenic agent. The first use was in 1995 [103], and since then several studies have reported successful treatment of GCTB with this agent [104]. Pegylated (PEG)-IFN has also been shown to have antiGCTB activity. A few case reports have reported the efficacy of interferon and pegylated interferon in the management of GCTB [105].

\section{Bisphosphonates}

Due to their anti-resorptive properties, some exploratory studies tested the efficacy of bisphosphonates in GCTB. It was shown that nitrogen-containing bisphosphonates induce apoptosis in both giant cells and stromal cells in vitro [106]. In a case-control study, pamidronate and zoledronate reduced local tumour recurrence (4.2 vs $30 \%$ in the control group, $p=0.056$ ) and controlled disease progression when used orally or intravenously as adjuvant therapy to intralesional curettage [107]. In 25 patients with recurrent and metastatic GCTB treated with bisphosphonates, stabilisation of disease was achieved in most cases refractory to conventional treatment [108]. In addition, there are case reports of successful local administration of zoledronic acid as adjuvant therapy during surgery [109]. However, they are not approved for use in this indication and more evidence is needed.

\section{Current guideline recommendations}

\section{$N C C N$}

In 2013, the National Comprehensive Cancer Network (NCCN) Clinical Practice Guidelines in Oncology for bone cancer added a new section on GCTB.

According to the version 1.2015 of these guidelines, workup begins with a history, physical examination, crosssectional imaging of the primary site, chest imaging, and biopsy to confirm the diagnosis. Bone scan is considered optional [110].

Regarding treatment (Table 4), the decision tree depends on whether the disease is localised or metastatic. For localised disease, the choice of surgery is next. If the tumour is resectable, excision is the primary option. If the tumour is resectable with unacceptable morbidity or unresectable, the options include serial embolization (primarily for tumours of the pelvis), denosumab, interferon, pegylated interferon, and/or radiotherapy [110].

For metastatic disease, the feasibility of surgery determines the treatment options. If the tumour is resectable, again the primary treatment pathway for localised disease should be followed and excision of metastatic sites considered. If the tumour is unresectable, treatment options include denosumab, interferon, pegylated interferon, radiotherapy, or observation [110].

NCCN Guidelines also contain recommendations for surveillance, which include physical examination, imaging of the surgical site as clinically indicated, and chest imaging every 6 months for 2 years and annually thereafter. For a resectable local tumour recurrence, chest imaging and denosumab may be considered before surgery [110].

\section{ESMO}

The 2014 ESMO guidelines for bone sarcomas [111] specify that treatment options for GCTB include intralesional curettage with or without adjuvant or en bloc excision. They also mention that recent work has suggested that denosumab obtains substantial tumour responses in large or unresectable or metastatic GCTB. For this reason, denosumab may be used to achieve cytoreduction allowing potentially curative surgery, or also in unresectable and rare metastatic disease, where treatment needs to be maintained to avoid progression [111].

Regarding surveillance, the recommendation for lowgrade bone sarcomas such as GCTB, include follow-up visits every 6 months for 2 years and then annually. However, they comment that late metastases as well as local recurrences and functional deficits may occur $>10$ years after diagnosis and that there is no universally accepted stopping point for tumour surveillance [111].

\section{Future expectations}

The knowledge of GCTB pathophysiology is rapidly evolving. The identification of the chemotactic factors secreted by stromal cells and involved in monocyte transformation into giant cells provides an opportunity to discover innovative treatments. The monoclonal antibody denosumab is the first drug agent with proven efficacy in GCTB by targeting one of these factors (RANKL). The main pending questions with denosumab include the evaluation of its possible benefits as neoadjuvant therapy [112], the optimal duration and schedule of treatment at long term to avoid recurrences, and its long-term safety. Some angiogenesis inhibitors have also been tested, such as calcitonin and interferon. IFN- $\alpha$ inhibits the expression of b-FGF and IL-8, two angiogenic factors. Other candidate therapies could be monoclonal antibodies directed against the involved cytokines or enzymes, such as anti-IL6, cathepsin inhibitors, anti-M-CSF or MMP-specific inhibitors [113]. The newer antibody-drug conjugates (ADCs), a novel class of highly potent drugs composed of an antibody (a whole antibody or an antibody fragment) linked to a cytotoxic drug could revolutionise treatment of GCTB [114]. Although few ADCs are currently available [115], 
Table 42015 NCCN recommendations for GCTB [110]

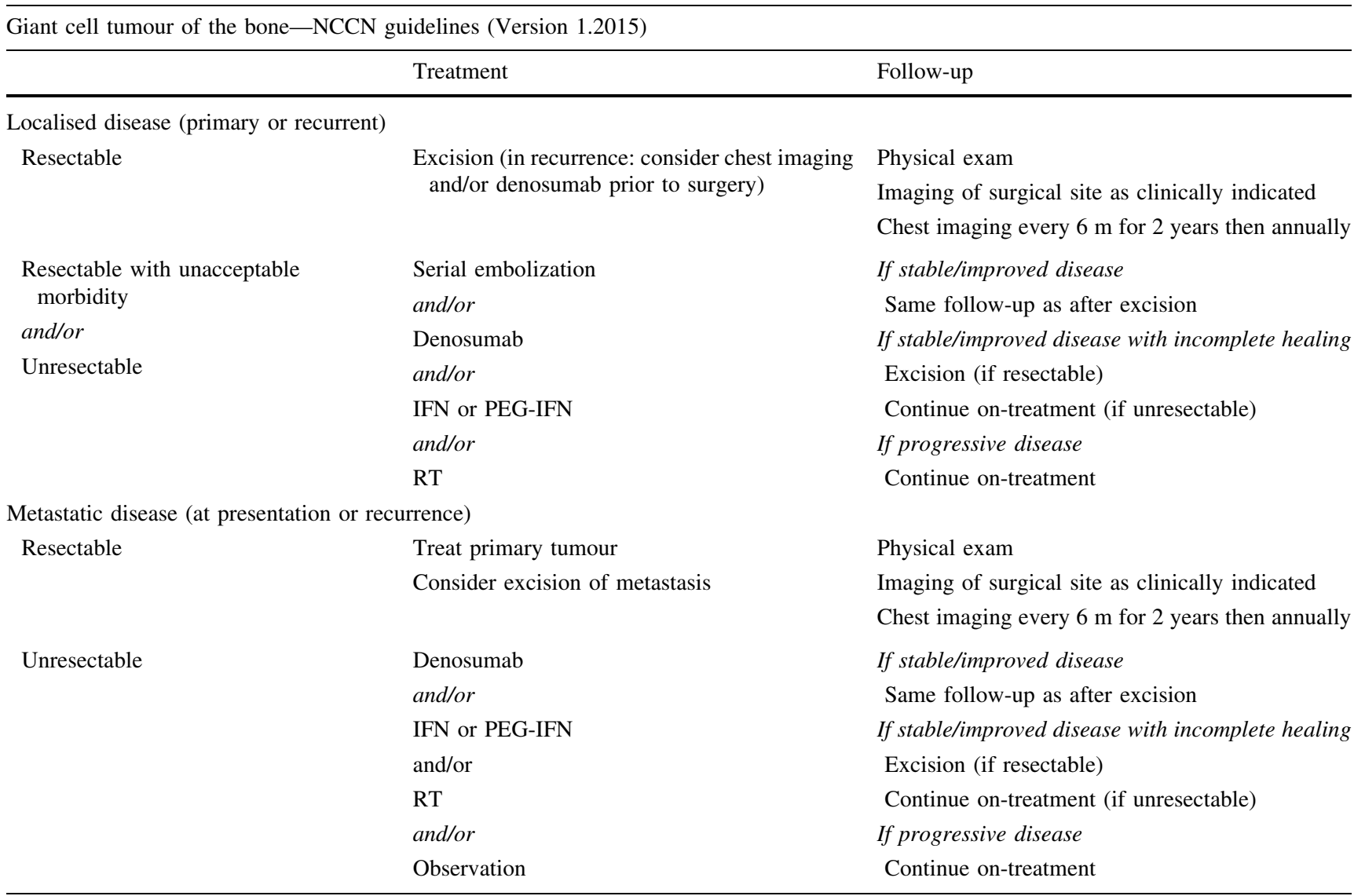

IFN interferon, $N C C N$ national comprehensive cancer network, $P E G$ pegylated, $R T$ radiotherapy

there are more than 20 compounds currently in clinical development, specific for a wide range of biological targets expressed by tumour cells [116]. It is hoped that, in the near future, some of them could be suitable for GCTB, in view of promising results in other cancers.

It also seems that targeting the neoplastic stromal cells could fight directly against the origin of tumour. Therapies blocking proliferation of stromal cells, such as drugs inhibiting cell cycle progression or telomerase activity could be effective. First, it would be necessary to identify specific markers for the stromal cells.

Recent findings suggest that the haemorrhagic component plays a fundamental role in the development of giant cells. In some instances, GCTB could be a reactive condition secondary to massive intraosseous haemorrhage, which attracts monocytes and forces their quick proliferation and conversion into multinucleated cells. There is also the hypothesis that poor matrix support to the vessels may underlie the haemorrhage that precedes tumour formation. Currently, the use of embolisation techniques and occlusion of the vessels helps reduce recurrence. Other treatments aimed to occlude the vessels and reinforce local osseous matrix support, such as laser and hormone therapies, could be also effective.

A more deep investigation on genetic predisposition may help to identify individuals at higher recurrence risk, in whom more aggressive therapies should be undertaken. For example, amplification of $20 \mathrm{q} 11.1$ seems to be a prognostic marker for adverse outcome [117] and warrants further investigation.

\section{Conclusions}

GCTB is an aggressive primary osteolytic bone tumour that causes substantial morbidity. GCTB tumours contain osteoclast-like giant cells that express RANK and stromal cells that express RANKL, a key mediator of osteoclast formation, activation, function, and survival. Excessive secretion of RANKL causes an imbalance in bone remodelling in favour of bone breakdown. Before the discovery of denosumab, surgical intervention was the only definitive therapy for patients with resectable tumours; however, it is associated with significant morbidity. Currently, denosumab 
constitutes an effective therapeutic option for treatment of adult patients with unresectable GCTB or in whom surgical resection is likely to result in severe morbidity. Denosumab provides objective tumour responses in $72 \%$ of patients, prolonging the time to surgery and reducing its morbidity in those patients with planned interventions. Denosumab is well tolerated, with ONJ and hypocalcemia; known risks are observed at low rates. The increasing knowledge of the molecular mechanisms involved in GCTB pathophysiology provides an opportunity for using new targeted therapies that may dramatically change the outcomes of GCTB in the next years.

Acknowledgments Writing assistance was funded by Amgen S.A. and provided by Dr. Neus Valveny from TFS Develop.

Conflict of interest TG and JV report being employees of Amgen and receiving stocks and stock options from Amgen. The other authors declare no conflict of interest.

Open Access This article is distributed under the terms of the Creative Commons Attribution License which permits any use, distribution, and reproduction in any medium, provided the original author(s) and the source are credited.

\section{References}

1. Beebe-Dimmer JL, Cetin K, Fryzek JP, Schuetze SM, Schwartz K. The epidemiology of malignant giant cell tumors of bone: an analysis of data from the Surveillance, Epidemiology and End Results Program (1975-2004). Rare Tumors. 2009;1:e52. doi:10.4081/rt.2009.e52.

2. Larsson SE, Lorentzon R, Boquist L. Giant-cell tumor of bone. A demographic, clinical, and histopathological study of all cases recorded in the Swedish Cancer Registry for the years 1958 through 1968. J Bone Joint Surg Am. 1975;57:167-73.

3. Liede A, Bach BA, Stryker S, Hernandez RK, Sobocki P, Bennett B, et al. Regional variation and challenges in estimating the incidence of giant cell tumor of bone. J Bone Joint Surg Am. 2014;96(23):1999-2007. doi:10.2106/ JBJS.N.00367.

4. Turcotte RE. Giant cell tumor of bone. Orthop Clin North Am. 2006;37:35-51. doi:10.1016/j.ocl.2005.08.005.

5. Turcotte RE, Wunder JS, Isler MH, Bell RS, Schachar N, Masri BA, et al. Giant cell tumor of long bone: a Canadian Sarcoma Group study. Clin Orthop. 2002;(397):248-58.

6. Mendenhall WM, Zlotecki RA, Scarborough MT, Gibbs CP, Mendenhall NP. Giant cell tumor of bone. Am J Clin Oncol. 2006;29:96-9. doi:10.1097/01. coc.0000195089.11620.b7.

7. Enneking WF, Spanier SS, Goodman MA. A system for the surgical staging of musculoskeletal sarcoma 1980. Clin Orthop. 2003;(415):4-18. doi:10.1097/ 01.blo.0000093891.12372.0f.

8. Campanacci M. Giant-cell tumor and chondrosarcomas: grading, treatment and results (studies of 209 and 131 cases). Recent Results Cancer Res Fortschritte Krebsforsch Prog Dans Rech Sur Cancer. 1976;54:257-61.

9. Novais EN, Shin AY, Bishop AT, Shives TC. Multicentric giant cell tumor of the upper extremities: 16 years of ongoing disease. J Hand Surg. 2011;36:1610-3. doi:10.1016/j.jhsa.2011.06.032.

10. Errani C, Ruggieri P, Asenzio MAN, Toscano A, Colangeli S, Rimondi E, et al. Giant cell tumor of the extremity: a review of 349 cases from a single institution. Cancer Treat Rev. 2010;36:1-7. doi:10.1016/j.ctrv.2009.09.002.

11. Bertoni F, Bacchini P, Staals EL. Malignancy in giant cell tumor of bone. Cancer. 2003;97:2520-9. doi:10.1002/cncr.11359.

12. Dominkus M, Ruggieri P, Bertoni F, Briccoli A, Picci P, Rocca M, et al. Histologically verified lung metastases in benign giant cell tumours-14 cases from a single institution. Int Orthop. 2006:30:499-504 doi:10.1007/s00264-006-0204-x.

13. Okamoto Y, Mathew S, Daw NC, Neel MD, McCarville MB, Dome JS, et al Giant cell tumor of bone with pulmonary metastases. Med Pediatr Oncol. 2003;41:454-9. doi:10.1002/mpo.10258.

14. Nahal A, Ajlan A, Alcindor T, Turcotte R. Dedifferentiated giant cell tumour of bone in the form of low-grade fibroblastic osteogenic sarcoma: case report of a unique presentation with follow-up. Curr Oncol. 2010;17:71-6.
15. Wülling M, Engels C, Jesse N, Werner M, Delling G, Kaiser E. The nature of giant cell tumor of bone. J Cancer Res Clin Oncol. 2001:127:467-74.

16. Werner M. Giant cell tumour of bone: morphological, biological and histogenetical aspects. Int Orthop. 2006;30:484-9. doi:10.1007/s00264-006-0215-7.

17. Wülling M, Delling G, Kaiser E. The origin of the neoplastic stromal cell in giant cell tumor of bone. Hum Pathol. 2003;34:983-93.

18. Roessner A, von Bassewitz DB, Schlake W, Thorwesten G, Grundmann E. Biologic characterization of human bone tumors III. Giant cell tumor of bone. A combined electron microscopical, histochemical, and autoradiographical study. Pathol Res Pract. 1984;178:431-40.

19. Kumta SM, Huang L. Expression of VEGF and MMP-9 in giant cell tumor of bone and other osteolytic lesions. Life Sci. 2003;73:1427-36. doi:10.1016/ S0024-3205(03)00434-X.

20. Itonaga I, Schulze E, Burge PD, Gibbons CLMH, Ferguson D, Athanasou NA Phenotypic characterization of mononuclear and multinucleated cells of giant cell reparative granuloma of small bones. J Pathol. 2002;198:30-6. doi:10. 1002/path.1184.

21. Miyamoto N, Higuchi Y, Tajima M, Ito M, Tsurudome M, Nishio M, et al. Spindle-shaped cells derived from giant-cell tumor of bone support differentiation of blood monocytes to osteoclast-like cells. J Orthop Res Off Publ Orthop Res Soc. 2000;18:647-54. doi:10.1002/jor.1100180418.

22. Morgan T, Atkins GJ, Trivett MK, Johnson SA, Kansara M, Schlicht SL, et al. Molecular profiling of giant cell tumor of bone and the osteoclastic localization of ligand for receptor activator of nuclear factor kappaB. Am J Pathol. 2005;167:117-28.

23. Liao TS, Yurgelun MB, Chang S-S, Zhang H-Z, Murakami K, Blaine TA, et al. Recruitment of osteoclast precursors by stromal cell derived factor-1 (SDF-1) in giant cell tumor of bone. J Orthop Res Off Publ Orthop Res Soc. 2005;23:203-9. doi:10.1016/j.orthres.2004.06.018.

24. Bridge JA, Neff JR, Bhatia PS, Sanger WG, Murphey MD. Cytogenetic findings and biologic behavior of giant cell tumors of bone. Cancer. 1990;65:2697-703.

25. Horton MA, Rimmer EF, Lewis D, Pringle JA, Fuller K, Chambers TJ. Cell surface characterization of the human osteoclast: phenotypic relationship to other bone marrow-derived cell types. J Pathol. 1984;144:281-94. doi:10. 1002/path.1711440410.

26. Flanagan AM, Nui B, Tinkler SM, Horton MA, Williams DM, Chambers TJ The multinucleate cells in giant cell granulomas of the jaw are osteoclasts. Cancer. 1988;62:1139-45.

27. Udagawa N, Takahashi N, Akatsu T, Tanaka H, Sasaki T, Nishihara T, et al. Origin of osteoclasts: mature monocytes and macrophages are capable of differentiating into osteoclasts under a suitable microenvironment prepared by bone marrow-derived stromal cells. Proc Natl Acad Sci USA. 1990;87:7260-4.

28. Branstetter DG, Nelson SD, Manivel JC, Blay J-Y, Chawla S, Thomas DM, et al. Denosumab induces tumor reduction and bone formation in patients with giant-cell tumor of bone. Clin Cancer Res Off J Am Assoc Cancer Res. 2012;18:4415-24. doi:10.1158/1078-0432.CCR-12-0578.

29. Atkins GJ, Kostakis P, Vincent C, Farrugia AN, Houchins JP, Findlay DM, et al. RANK Expression as a cell surface marker of human osteoclast precursors in peripheral blood, bone marrow, and giant cell tumors of bone. J Bone Miner Res Off J Am Soc Bone Miner Res. 2006;21:1339-49. doi:10. 1359/jbmr.060604.

30. Huang L, Xu J, Wood DJ, Zheng MH. Gene expression of osteoprotegerin ligand, osteoprotegerin, and receptor activator of NF-kappaB in giant cell tumor of bone: possible involvement in tumor cell-induced osteoclast-like cell formation. Am J Pathol. 2000;156:761-7.

31. Kartsogiannis V, Zhou H, Horwood NJ, Thomas RJ, Hards DK, Quinn JM, et al. Localization of RANKL (receptor activator of NF kappa B ligand) mRNA and protein in skeletal and extraskeletal tissues. Bone. 1999;25:525-34.

32. Roux S, Amazit L, Meduri G, Guiochon-Mantel A, Milgrom E, Mariette X. RANK (receptor activator of nuclear factor kappa B) and RANK ligand are expressed in giant cell tumors of bone. Am J Clin Pathol. 2002;117:210-6. doi:10.1309/BPET-F2PE-P2BD-J3P3.

33. Burgess TL, Qian Y, Kaufman S, Ring BD, Van G, Capparelli C, et al. The ligand for osteoprotegerin (OPGL) directly activates mature osteoclasts. J Cell Biol. 1999;145:527-38.

34. Lacey DL, Timms E, Tan HL, Kelley MJ, Dunstan CR, Burgess T, et al. Osteoprotegerin ligand is a cytokine that regulates osteoclast differentiation and activation. Cell. 1998;93:165-76.

35. Yasuda H, Shima N, Nakagawa N, Yamaguchi K, Kinosaki M, Mochizuki S, et al. Osteoclast differentiation factor is a ligand for osteoprotegerin/osteoclastogenesis-inhibitory factor and is identical to TRANCE/RANKL. Proc Natl Acad Sci USA. 1998;95:3597-602.

36. Atkins GJ, Haynes DR, Graves SE, Evdokiou A, Hay S, Bouralexis S, et al Expression of osteoclast differentiation signals by stromal elements of giant cell tumors. J Bone Miner Res Off J Am Soc Bone Miner Res. 2000;15:640-9. doi:10.1359/jbmr.2000.15.4.640.

37. Cowan RW, Singh G. Giant cell tumor of bone: a basic science perspective. Bone. 2013;52:238-46. doi:10.1016/j.bone.2012.10.002.

38. Kim Y, Nizami S, Goto H, Lee FY. Modern interpretation of giant cell tumor of bone: predominantly osteoclastogenic stromal tumor. Clin Orthop Surg. 2012;4:107-16. doi:10.4055/cios.2012.4.2.107. 
39. Gorunova L, Vult von Steyern F, Storlazzi CT, Bjerkehagen B, Follerås G, Heim S, et al. Cytogenetic analysis of 101 giant cell tumors of bone: nonrandom patterns of telomeric associations and other structural aberrations. Genes Chromosomes Cancer. 2009;48:583-602. doi:10.1002/gcc.20667.

40. Bardi G, Pandis N, Mandahl N, Heim S, Sfikas K, Willén H, et al. Chromosomal abnormalities in giant cell tumors of bone. Cancer Genet Cytogenet. 1991;57:161-7.

41. Haque AU, Moatasim A. Giant cell tumor of bone: a neoplasm or a reactive condition? Int J Clin Exp Pathol. 2008;1:489-501.

42. Langer F, Pritzker KP, Gross AE, Shapiro II. Giant cell tumor associated with trauma. Clin Orthop. 1982;(164):245-8.

43. Goldring SR, Roelke MS, Petrison KK, Bhan AK. Human giant cell tumors of bone identification and characterization of cell types. J Clin Invest. 1987;79:483-91. doi:10.1172/JCI112838.

44. Byers VS, Levin AS, Johnston JO, Hackett AJ. Quantitative immunofluorescence studies of the tumor antigen-bearing cell in giant cell tumor of bone and osteogenic sarcoma. Cancer Res. 1975;35:2520-31.

45. James IE, Dodds RA, Olivera DL, Nuttall ME, Gowen M. Human osteoclastoma-derived stromal cells: correlation of the ability to form mineralized nodules in vitro with formation of bone in vivo. $\mathrm{J}$ Bone Miner Res Off $\mathrm{J}$ Am Soc Bone Miner Res. 1996;11:1453-60. doi:10.1002/jbmr.5650111012.

46. Balke M, Neumann A, Szuhai K, Agelopoulos K, August C, Gosheger G, et al. A short-term in vivo model for giant cell tumor of bone. BMC Cancer. 2011;11:241. doi:10.1186/1471-2407-11-241.

47. Tubbs WS, Brown LR, Beabout JW, Rock MG, Unni KK. Benign giant-cell tumor of bone with pulmonary metastases: clinical findings and radiologic appearance of metastases in 13 cases. AJR Am J Roentgenol. 1992;158:331-4. doi:10.2214/ajr.158.2.1729794.

48. Alberghini M, Kliskey K, Krenacs T, Picci P, Kindblom L, Forsyth R, et al. Morphological and immunophenotypic features of primary and metastatic giant cell tumour of bone. Virchows Arch Int J Pathol. 2010;456:97-103. doi:10.1007/s00428-009-0863-2

49. McDonald DJ, Sim FH, McLeod RA, Dahlin DC. Giant-cell tumor of bone. J Bone Joint Surg Am. 1986;68:235-42.

50. Saiz P, Virkus W, Piasecki P, Templeton A, Shott S, Gitelis S. Results of giant cell tumor of bone treated with intralesional excision. Clin Orthop. 2004;424:221-6.

51. Malek F, Krueger P, Hatmi ZN, Malayeri AA, Faezipour H, O’Donnell RJ. Local control of long bone giant cell tumour using curettage, burring and bone grafting without adjuvant therapy. Int Orthop. 2006;30:495-8. doi:10.1007/ s00264-006-0146-3.

52. Kivioja AH, Blomqvist C, Hietaniemi K, Trovik C, Walloe A, Bauer HCF, et al. Cement is recommended in intralesional surgery of giant cell tumors: a Scandinavian Sarcoma Group study of 294 patients followed for a median time of 5 years. Acta Orthop. 2008;79:86-93. doi:10.1080/ 17453670710014815.

53. Boons HW, Keijser LCM, Schreuder HWB, Pruszczynski M, Lemmens JAM, Veth RPH. Oncologic and functional results after treatment of giant cell tumors of bone. Arch Orthop Trauma Surg. 2002;122:17-23.

54. Su Y-P, Chen W-M, Chen T-H. Giant-cell tumors of bone: an analysis of 87 cases. Int Orthop. 2004;28:239-43. doi:10.1007/s00264-004-0564-Z.

55. Guo W, Sun X, Zang J, Qu H. Intralesional excision versus wide resection for giant cell tumor involving the acetabulum: which is better? Clin Orthop. 2012;470:1213-20. doi:10.1007/s11999-011-2190-6.

56. Labs K, Perka C, Schmidt RG. Treatment of stages 2 and 3 giant-cell tumor. Arch Orthop Trauma Surg. 2001;121:83-6.

57. Saini R, Bali K, Bachhal V, Mootha AK, Dhillon MS, Gill SS. En bloc excision and autogenous fibular reconstruction for aggressive giant cell tumor of distal radius: a report of 12 cases and review of literature. J Orthop Surg. 2011;6:14. doi:10.1186/1749-799X-6-14.

58. Futani H, Okumura Y, Fukuda Y, Fukunaga S, Hasegawa S, Yoshiya S. Giant cell tumor of the sternum: a case report and review of the literature. Anticancer Res. 2008;28:4117-20.

59. Oh JH, Yoon PW, Lee SH, Cho HS, Kim WS, Kim H-S. Surgical treatment of giant cell tumour of long bone with anhydrous alcohol adjuvant. Int Orthop. 2006;30:490-4. doi:10.1007/s00264-006-0154-3.

60. Blackley HR, Wunder JS, Davis AM, White LM, Kandel R, Bell RS. Treatment of giant-cell tumors of long bones with curettage and bone-grafting. J Bone Joint Surg Am. 1999;81:811-20.

61. Liu HS, Wang JW. Treatment of giant cell tumor of bone: a comparison of local curettage and wide resection. Chang Yi Xue Za Zhi Chang Ji Nian Yi Yuan Chang Gung Med J Chang Gung Meml Hosp. 1998;21:37-43.

62. Rastogi S, Prashanth I, Khan SA, Trikha V, Mittal R. Giant cell tumor of bone: is curettage the answer? Indian J Orthop. 2007;41:109-14. doi:10.4103/ 0019-5413.32040.

63. Yu X, Xu M, Song R, Fu Z, Liu X. Long-term outcome of giant cell tumors of bone around the knee treated by en bloc resection of tumor and reconstruction with prosthesis. Orthop Surg. 2010;2:211-7. doi:10.1111/j.1757-7861.2010. 00089.x.

64. Deheshi BM, Jaffer SN, Griffin AM, Ferguson PC, Bell RS, Wunder JS. Joint salvage for pathologic fracture of giant cell tumor of the lower extremity. Clin Orthop. 2007;459:96-104. doi:10.1097/BLO.0b013e31805d85e4.
65. Lee FY, Montgomery M, Hazan EJ, Keel SB, Mankin HJ, Kattapuram S. Recurrent giant-cell tumor presenting as a soft-tissue mass. A report of four cases. J Bone Joint Surg Am. 1999;81:703-7.

66. Prosser GH, Baloch KG, Tillman RM, Carter SR, Grimer RJ. Does curettage without adjuvant therapy provide low recurrence rates in giant-cell tumors of bone? Clin Orthop. 2005;(435):211-8.

67. Balke M, Schremper L, Gebert C, Ahrens H, Streitbuerger A, Koehler G, et al. Giant cell tumor of bone: treatment and outcome of 214 cases. J Cancer Res Clin Oncol. 2008;134:969-78. doi:10.1007/s00432-008-0370-x.

68. Kafchitsas K, Habermann B, Proschek D, Kurth A, Eberhardt C. Functional results after giant cell tumor operation near knee joint and the cement radiolucent zone as indicator of recurrence. Anticancer Res. 2010;30:3795-9.

69. Zhen W, Yaotian H, Songjian L, Ge L, Qingliang W. Giant-cell tumour of bone. The long-term results of treatment by curettage and bone graft. J Bone Joint Surg Br. 2004;86:212-6.

70. Malawer MM, Bickels J, Meller I, Buch RG, Henshaw RM, Kollender Y. Cryosurgery in the treatment of giant cell tumor. A long-term followup study. Clin Orthop. 1999;(359):176-88.

71. Gortzak Y, Kandel R, Deheshi B, Werier J, Turcotte RE, Ferguson PC, et al. The efficacy of chemical adjuvants on giant-cell tumour of bone. An in vitro study. J Bone Joint Surg Br. 2010;92:1475-9.

72. Jones KB, DeYoung BR, Morcuende JA, Buckwalter JA. Ethanol as a local adjuvant for giant cell tumor of bone. Iowa Orthop J. 2006;26:69-76.

73. Eckardt JJ, Grogan TJ. Giant cell tumor of bone. Clin Orthop. 1986;(204):45-58.

74. Nicholson NC, Ramp WK, Kneisl JS, Kaysinger KK. Hydrogen peroxide inhibits giant cell tumor and osteoblast metabolism in vitro. Clin Orthop. 1998;347:250-60.

75. Ward WG Sr, Li G 3rd. Customized treatment algorithm for giant cell tumor of bone: report of a series. Clin Orthop. 2002;(397):259-70.

76. Lu Y, Fan Q, Wang Q. Treatment of giant cell tumor of bone. Iowa Orthop J. 1988;8:39-42.

77. Dürr HR, Maier M, Jansson V, Baur A, Refior HJ. Phenol as an adjuvant for local control in the treatment of giant cell tumour of the bone. Eur J Surg Oncol J Eur Soc Surg Oncol Br Assoc Surg Oncol. 1999;25:610-8. doi:10. 1053/ejso.1999.0716.

78. Trieb K, Bitzan P, Lang S, Dominkus M, Kotz R. Recurrence of curetted and bone-grafted giant-cell tumours with and without adjuvant phenol therapy. Eur J Surg Oncol J Eur Soc Surg Oncol Br Assoc Surg Oncol. 2001;27:200-2. doi:10.1053/ejso.2000.1086.

79. McCarthy EF. Giant-cell tumor of bone: an historical perspective. Clin Orthop. 1980;(153):14-25.

80. Malone S, O'Sullivan B, Catton C, Bell R, Fornasier V, Davis A. Long-term follow-up of efficacy and safety of megavoltage radiotherapy in high-risk giant cell tumors of bone. Int J Radiat Oncol Biol Phys. 1995;33:689-94. doi:10.1016/0360-3016(95)00159-V.

81. Micke O, Bruns F, Eich HT, Muecke R, Buentzel J, Willich N, et al. Radiation therapy for giant cell tumors of bone: Long-term results of a multicenter study in Germany. Int J Radiat Oncol Biol Phys. 2005;63:S108. doi:10.1016/j. ijrobp.2005.07.183.

82. Hug EB, Muenter MW, Adams JA, de Vries A, Rosenberg AE, Munzenrider JE. 3-D-conformal radiation therapy for pediatric giant cell tumors of the skull base. Strahlenther Onkol Organ Dtsch Röntgenges Al. 2002;178:239-44.

83. Roeder F, Timke C, Zwicker F, Thieke C, Bischof M, Debus J, et al. Intensity modulated radiotherapy (IMRT) in benign giant cell tumors-a single institution case series and a short review of the literature. Radiat Oncol Lond Engl. 2010;5:18. doi:10.1186/1748-717X-5-18.

84. Brien EW, Mirra JM, Kessler S, Suen M, Ho JK, Yang WT. Benign giant cell tumor of bone with osteosarcomatous transformation ("dedifferentiated" primary malignant GCT): report of two cases. Skeletal Radiol. 1997;26:246-55.

85. Van der Heijden L, Dijkstra PDS, van de Sande MAJ, Kroep JR, Nout RA, van Rijswijk CSP, et al. The clinical approach toward giant cell tumor of bone. Oncologist. 2014;19:550-61. doi:10.1634/theoncologist.2013-0432.

86. Layalle I, Flandroy P, Trotteur G, Dondelinger RF. Arterial embolization of bone metastases: is it worthwhile? J Belge Radiol. 1998;81:223-5.

87. Lewis VO, Wei A, Mendoza T, Primus F, Peabody T, Simon MA. Argon beam coagulation as an adjuvant for local control of giant cell tumor. Clin Orthop. 2007;454:192-7. doi:10.1097/01.blo.0000238784.98606.d4.

88. Onishi H, Kaya M, Wada T, Nagoya S, Sasaki M, Yamashita T. Giant cell tumor of the sacrum treated with selective arterial embolization. Int J Clin Oncol. 2010;15:416-9. doi:10.1007/s10147-010-0048-7.

89. Owen RJT. Embolization of musculoskeletal bone tumors. Semin Interv Radiol. 2010;27:111-23. doi:10.1055/s-0030-1253510.

90. Ruggieri P, Mavrogenis AF, Ussia G, Angelini A, Papagelopoulos PJ, Mercuri M. Recurrence after and complications associated with adjuvant treatments for sacral giant cell tumor. Clin Orthop. 2010;468:2954-61. doi:10.1007/s11999010-1448-8.

91. Emori M, Kaya M, Sasaki M, Wada T, Yamaguchi T, Yamashita T. Preoperative selective arterial embolization as a neoadjuvant therapy for proximal 
humerus giant cell tumor of bone: radiological and histological evaluation. Jpn J Clin Oncol. 2012;42:851-5. doi:10.1093/jjco/hys090.

92. Lin PP, Guzel VB, Moura MF, Wallace S, Benjamin RS, Weber KL, et al Long-term follow-up of patients with giant cell tumor of the sacrum treated with selective arterial embolization. Cancer. 2002;95:1317-25. doi:10.1002/ cncr. 10803.

93. Hosalkar HS, Jones KJ, King JJ, Lackman RD. Serial arterial embolization for large sacral giant-cell tumors: mid- to long-term results. Spine. 2007;32:1107-15. doi:10.1097/01.brs.0000261558.94247.8d.

94. Amgen SA (2014) XGEVA ${ }^{\circledR}$ (denosumab) Summary of Product Characteristics (SmPC). http://www.ema.europa.eu/docs/en_GB/document_library/ EPAR_-_Product_Information/human/002173/WC500110381.pdf. Accessed 2 Oct 2014.

95. XGEVA ${ }^{\circledR}$ (denosumab) Prescribing information. http://www.accessdata.fda gov/drugsatfda_docs/label/2013/125320s094lbl.pdf. Accessed 2 Oct 2014.

96. Bekker PJ, Holloway DL, Rasmussen AS, Murphy R, Martin SW, Leese PT, et al. A single-dose placebo-controlled study of AMG 162, a fully human monoclonal antibody to RANKL, in postmenopausal women. J Bone Miner Res Off J Am Soc Bone Miner Res. 2004;19:1059-66. doi:10.1359/JBMR. 040305 .

97. Body J-J, Facon T, Coleman RE, Lipton A, Geurs F, Fan M, et al. A study of the biological receptor activator of nuclear factor-kappaB ligand inhibitor, denosumab, in patients with multiple myeloma or bone metastases from breast cancer. Clin Cancer Res Off J Am Assoc Cancer Res. 2006;12:1221-8. doi:10. 1158/1078-0432.CCR-05-1933.

98. Chawla S, Henshaw R, Seeger L, Choy E, Blay J-Y, Ferrari S, et al. Safety and efficacy of denosumab for adults and skeletally mature adolescents with giant cell tumour of bone: interim analysis of an open-label, parallel-group, phase 2 study. Lancet Oncol. 2013;14:901-8. doi:10.1016/S1470-2045(13)70277-8.

99. Thomas D, Henshaw R, Skubitz K, Chawla S, Staddon A, Blay J-Y, et al. Denosumab in patients with giant-cell tumour of bone: an open-label, phase 2 study. Lancet Oncol. 2010;11:275-80. doi:10.1016/S1470-2045(10)70010-3.

100. Aghaloo TL, Felsenfeld AL, Tetradis S. Osteonecrosis of the jaw in a patient on Denosumab. J Oral Maxillofac Surg Off J Am Assoc Oral Maxillofac Surg. 2010;68:959-63. doi:10.1016/j.joms.2009.10.010.

101. Chakarun CJ, Forrester DM, Gottsegen CJ, Patel DB, White EA, Matcuk GR Jr. Giant cell tumor of bone: review, mimics, and new developments in treatment. Radiogr Rev Publ Radiol Soc N Am Inc. 2013;33:197-211. doi:10. 1148/rg.331125089.

102. Karras NA, Polgreen LE, Ogilvie C, Manivel JC, Skubitz KM, Lipsitz E. Denosumab treatment of metastatic giant-cell tumor of bone in a 10-year-old girl. J Clin Oncol Off J Am Soc Clin Oncol. 2013:31:e200-2. doi:10.1200/ JCO.2012.46.4255.

103. Kaban LB, Mulliken JB, Ezekowitz RA, Ebb D, Smith PS, Folkman J. Antiangiogenic therapy of a recurrent giant cell tumor of the mandible with interferon alfa-2a. Pediatrics. 1999;103:1145-9.
104. Kaban LB, Troulis MJ, Ebb D, August M, Hornicek FJ, Dodson TB. Antiangiogenic therapy with interferon alpha for giant cell lesions of the jaws. J Oral Maxillofac Surg Off J Am Assoc Oral Maxillofac Surg. 2002;60:1103-11 discussion 1111-1113.

105. Yasko AW. Interferon therapy for giant cell tumor of bone. Curr Opin Orthop. 2006;17:568-72. doi:10.1097/BCO.0b013e328010913b.

106. Cheng YY, Huang L, Lee KM, Xu JK, Zheng MH, Kumta SM. Bisphosphonates induce apoptosis of stromal tumor cells in giant cell tumor of bone. Calcif Tissue Int. 2004;75:71-7. doi:10.1007/s00223-004-0120-2.

107. Tse LF, Wong KC, Kumta SM, Huang L, Chow TC, Griffith JF. Bisphosphonates reduce local recurrence in extremity giant cell tumor of bone: a case-control study. Bone. 2008;42:68-73. doi:10.1016/j.bone.2007.08.038.

108. Balke M, Campanacci L, Gebert C, Picci P, Gibbons M, Taylor R, et al. Bisphosphonate treatment of aggressive primary, recurrent and metastatic giant cell tumour of bone. BMC Cancer. 2010;10:462. doi:10.1186/14712407-10-462.

109. Nishisho T, Hanaoka N, Endo K, Takahashi M, Yasui N. Locally administered zoledronic acid therapy for giant cell tumor of bone. Orthopedics. 2011;34:e312-5. doi:10.3928/01477447-20110526-22.

110. NCCN. Bone cancer-NCCN guidelines (Version 1.2015). http://www.ncen. org. Accessed 2 Oct 2014.

111. Group TESNW. Bone sarcomas: ESMO clinical practice guidelines for diagnosis, treatment and follow-up. Ann Oncol. 2014;25:iii113-23. doi:10. 1093/annonc/mdu256.

112. Agarwal A, Larsen BT, Buadu LD, Dunn J, Crawford R, Daniel J, et al. Denosumab chemotherapy for recurrent giant-cell tumor of bone: a case report of neoadjuvant use enabling complete surgical resection. Case Rep Oncol Med. 2013;2013:496351. doi:10.1155/2013/496351.

113. Cheng H, Clarkson PW, Gao D, Pacheco M, Wang Y, Nielsen TO. Therapeutic antibodies targeting CSF1 impede macrophage recruitment in a xenograft model of tenosynovial giant cell tumor. Sarcoma. 2010;. doi:10.1155/ 2010/174528.

114. Li GN, Wang SP, Xue X, Qu XJ, Liu HP. Monoclonal antibody-related drugs for cancer therapy. Drug Discov Ther. 2013;7:178-84.

115. Sievers EL, Senter PD. Antibody-drug conjugates in cancer therapy. Annu Rev Med. 2013;64:15-29. doi:10.1146/annurev-med-050311-201823.

116. Perez HL, Cardarelli PM, Deshpande S, Gangwar S, Schroeder GM, Vite GD, et al. Antibody-drug conjugates: current status and future directions. Drug Discov Today. 2014;19:869-81. doi:10.1016/j.drudis.2013.11.004.

117. Smith LT, Mayerson J, Nowak NJ, Suster D, Mohammed N, Long S, et al. 20q11.1 amplification in giant-cell tumor of bone: array CGH, FISH, and association with outcome. Genes Chromosomes Cancer. 2006;45:957-66. doi: $10.1002 / \mathrm{gcc} .20354$. 